\title{
Islamic Banking
}

Mervyn K. Lewis and Latifa M. Algaoud Cheltenham, UK: Edward Elgar, 2001. 274 pages.

Islamic Banking is an outstanding example of collaboration among Muslim and non-Muslim scholars interested in integrating "Western-based literature with that developed in the Islamic tradition." Stating that Islamic banking, although widespread, remains "poorly understood" in the Muslim world and an "enigma" in the West, the authors seek to clarify many matters. The book's main themes are Christian and Islamic positions on usury/riba' (chapter 8); the foundations (chapters 2 and 3), theories (chapter 5), application (chapters 5, 6, 7, and 9), and progress (chapters 1 and 9) of Islamic banking; and an analysis of Islamic banking in light of 
current theories of financial intermediation (chapter 4) and corporate governance (chapter 7).

The book highlights Islamic and Christian commonalities on issues pertinent to banking and finance. While stating that Christianity, Hinduism, Judaism, and Islam prohibit usury, "Islam is the only major religion which maintains a prohibition on usury" due to its prominence in the Qur'an. The issue of riba' is perplexing, for despite warnings of severe consequences to those who engage in it, the Qur'an is silent on its exact nature. Unfortunately, successive generations of scholars have so confused matters that no one can say exactly what riba' is. For example, a majority of scholars regarded bank interest as riba' and, therefore, made the need for an interest-free Islamic banking system inevitable, whereas 21 jurists at Egypt's al-Azhar recently proclaimed a ruling that legitimizes interest.

Traditionally, Islamic religious terminology has made no conceptual difference made between interest and usury (high interest). However, a comparison of Christian and Islamic attitudes to the ban shows a striking similarity between the "devices used by Christians" and the "financing instruments used by Islamic banks today" to circumvent the prohibition. Both groups considered usury an exploitation that lacks scriptural warrant, although in practice many stratagems were adopted to circumvent the prohibition, such as distinguishing between usury and interest (compensating for loss and/or sacrificing the gain due to a loan), and combining a service charge and interest in the bill of exchange transactions to "disguise domestic credit transactions in the form of currency exchange." Likewise, by using hiyal (legal device), "Muslim merchants utilized the potential of the bill of exchange to (and perhaps beyond) the limits of law." In fact, the authors conjecture that Muslims conveyed many of these hiyal to medieval Europe through the triangular trade and commerce among the Islamic realm, Byzantium, and Europe. Islamic banking is seemingly a replay of the $700 \mathrm{CE}$ ruses, under the rubric of Islamization, to avoid adopting indigenous Islamic morés. However, while Christians disguised usury (riba') as interest, Muslims disguise it as profit-sharing.

In Islamic jurisprudence, banking laws fall under the category of mu'amalat (relations between human beings). Islamic banking laws and transactions must comply with certain religious imperatives: no interest (riba'), uncertainty (gharar), or dealing in prohibited (haram) goods and activities; payment of the tithe (zakat); and solidarity (takaful) among Muslims. To comply, Islamic banking transactions are conducted on the 
basis of partnerships (mudarabah and musharakah), sales (bay'), hire (ijarah), gift (hiba'), and loan ('ariyah) contracts.

The book outlines two Islamic banking models advanced by Chapra and Ismail. Chapra's approach favors achieving socioeconomic development through Islamic banking, while Ismail considers Islamic banking a profit-making commercial enterprise. On the basis of the brief history of Islamic banking, the authors conclude that for Islamic banking to succeed, the activities of Islamic financial institutions have to be commercial rather than socioeconomic, provide a full range of commercial banking services compatible with Islamic norms, and avoid hostility with government authorities. Here, the authors could have strengthened their discussion by augmenting it with models proposed by Anwar and El-Naggar (who pioneered Islamic banking in Mit Ghamr), which allow the achievement of both commercial and socioeconomic objectives.

The book also analyzes Islamic banking against the backdrop of modern theories of financial intermediation regarding transactions costs, information problems, and designing incentive-compatible contracts. Search, verification, monitoring, and enforcement costs inhibit the financing process and "define the functions of banks as producers of information." In this regard, "monitoring" to ensure that funds are used in the promised way, "contracts enforcement" to ensure repayment of borrowed funds, and "risk-sharing" functions distinguish Islamic banking from conventional banking. The costs of intermediation, the depositors' behavior and attitudes, the importance of monitoring costs for contract form, and the role of religious precepts in reducing incentive problems are deemed central to the success of the special Islamic modes of finance.

Contract design literature demonstrates that debt contracts are superior in the presence of costly verification, moral hazard, and adverse selection problems. However, equity contracts, which characterize Islamic banking, dominate debt contracts, for they mitigate adverse selection problems relating to risks connected with the investment project. Moreover, modern literature addressing the role of banks as "liquidity insurers" favors mutual fund (unit trust) banking, which is akin to Islamic banking. Being equity-based, an Islamic banking system is distinct due to its treatment of depositors as bank shareholders. Islamic banking, again being equity-based, differs from the Anglo-Saxon market-based banking and the German-Japanese type universal banking.

These Islamic financial arrangements, with real transactions rather than purely financial ones, imply a quite different degree of involvement, 
and by corollary governance structures, since depositors have a direct stake in the bank's investments and equity participation. In addition, an Islamic bank is subject to an additional layer of controls, since its investments and financing must be in strict conformity with the Shari ah and meet the Muslim community's expectations.

The book is a noteworthy addition to the literature on Islamic banking and finance, for its inclusion of modern intermediation and corporate governance analysis in Islamic banking sets it apart from other available books. Islamic Banking would have benefited from a more coherent organization. For example, the discussion on several topics, including rib $\mathbb{F}^{\prime}$ and Islamization, is scattered throughout the book. Tying these together would have made the subject matter's presentation more unified and easier to follow.

Muhammad Anwar International Islamic University Kuala Lumpur, Malaysia 